\title{
Peningkatan Hasil Belajar Tematik Terpadu Menggunakan Strategi Inkuiri di Sekolah Dasar
}

\author{
Andha Rista Virliana1), Reinita ${ }^{2)}$ \\ Pendidikan Guru Sekolah Dasar, Universitas Negeri Padang \\ E-mail: andharista.verliana714@gmail.com ${ }^{1)}$, reinita.rei04@gmail.com ${ }^{2)}$
}

\begin{abstract}
Abstrak
Tujuan dari penelitian ini adalah untuk mendeskripsikan peningkatan hasil belajar tematik terpadu menggunakan strategi pembelajaran inkuiri di Kelas IV SDN 42 Kubang Kabupaten Pesisir Selatan. Pada penelitian ini menerapkan jenis penelitian PTK menggunakan pendekatan kualitatif dan kuantitatif. Dimana penelitian ini dilakukan terhadap siswa kelas IV SDN 42 Kubang yang berjumlah 18 orang yang terdiri dari 13 orang siswa laki-laki dan 5 orang siswa perempuan. Hasil penelitian menunjukkan: a) penilaian Rencana Pelaksanaan Pembelajaran siklus I diperoleh rata-rata $79,16 \%(\mathrm{C})$, dan pada siklus II meningkat menjadi $94,44 \%$ (SB). b) Pengamatan pada aspek guru siklus I diperoleh rata-rata79,69\% (C) dan pada siklus II meningkat menjadi $90,6 \%$ (SB). c) Pengamatan pada aspek siswa siklus I diperoleh rata-rata 76,56\% (C) dan pada siklus II meningkat menjadi 93,75\% (SB). Dengan demikian strategi Inkuiri dapat meningkatkan hasil belajar tematik terpadu disekolah dasar.
\end{abstract}

Kata kunci: Hasil Belajar, Strategi Pembelajaran Inkuiri

\begin{abstract}
The purpose of this study is to describe the improvement of integrated thematic learning outcomes using inquiry learning strategies in Class IV SDN 42 Kubang, Pesisir Selatan Regency. This research applies the type of PTK research using qualitative and quantitative approaches. Where this research was conducted on the fourth grade students of SDN 42 Kubang, amounting to 18 people consisting of 13 male students and 5 female students. The results showed: a) the assessment of the Learning Implementation Plan cycle I obtained an average of $79.16 \%(\mathrm{C})$, and in cycle II increased to $94.44 \%$ (SB). b) Observations on the teacher aspect in the first cycle obtained an average of $79.69 \%$ (C) and in the second cycle it increased to $90.6 \%$ (SB). c) Observations on the aspects of students in the first cycle obtained an average of $76.56 \%$ (C) and in the second cycle increased to $93.75 \%$ (SB). Thus the Inquiry strategy can improve integrated thematic learning outcomes in elementary schools.
\end{abstract}

\section{Keywords: Learning Outcomes, Inquiry Learning Strategies}

\section{PENDAHULUAN}

Kurikulum adalah suatu acuan yang dirancang oleh lembaga pendidikan dengan tujuan mencapai pendidikan. Hal ini sesusai ditegaskan oleh Reinita (2019) kurikulum adalah "Kurikulum merupakan suatu perangkat yang dijadikan pedoman dalam mengembangkan suatu proses pembelajaran yang berhubungan dengan kegiatan siswa untuk mencapai tujuan pendidikan dan pembelajaran".

Menurut Purnamasari, Yunisrul, dan Desyandri (2018:11) dalam jurnalnya "Pembelajaran merupakan proses komunikasi dua arah, mengajar dilakukan oleh pihak guru sebagai pendidik, sedangkan belajar dilakukan oleh peserta didik atau murid".

Sedangkan Sukerti (dalam Reinita, 2019:61) mengatakan Pembelajaran tematik terpadu adalah "pembelajaran yang secara sengaja mengaitkan beberapa aspek baik dalam intra mata pelajaran maupun antar mata pelajaran sehingga siswa memperoleh pengatahuan dan keterampilan secara utuh sehingga proses pembelajaran menjadi bermakna bagi siswa". Pembelajaran tematik terpadu ditujukan agar siswa dapat aktif dan mampu mengembangkan potensinya dalam pembelajaran, karena konsep pembelajaran 
tematik ialaah pembelajara yang menekankan pada aktivitas siswa dalam belajar, pada dasarnya pembelajaran terpadu dikembangkan untuk menciptakan pembelajaran yang di dalamnya siswa sendiri aktif secara mentalemmbangun pengetahuannya yang dilandasi oleh struktur kognitif yang telah dimilikinya. (Majid dalam Reinita, 2019:70).

Berdasarkan hasil observasi yang peneliti lakukan di kelas IV SDN 42 Kubang Kabupaten Pesisir Selatan pada tanggal 24 Agustus hingga 28 Agustus dalam proses pembelajarannya belum maksimal, karena masih terdapat beberapa permasalahan diantaranya yaitu : (1) Peserta didik kurang termotivasi dalam mengikuti pembelajaran. (2) Peserta didik kurang memperoleh pengalaman langsung saat proses pembelajaran. 3) peserta didik kurang aktif dalam pembelajaran karena hanya mendengarkan guru saja. (4) pemisahan muatan mata pelajaran masih terlihat. (5) Peserta didik kurang mendapatkan kesempatan dalam mengembangkan minat dan bakat serta pengetahuan yang dimilikinya.

Permasalahan disebabkan oleh; (1) Dalam pembelajaran guru kurang menggunakan strategi pembelajaran dan hanya bersumber sebatas dari buku guru saja. (2) Guru kurang memberikan kesempatan kepada peserta didik dalam mencari dan mengolah informasi sehingga peserta didik tidak bisa menemukan jawaban atau pertanyaan secara sendiri dalam pembelajaran. (3) Guru belum menggunakan media pembelajaran sehingga peserta didik merasa bosan. (4) Rencana pelaksanaan pembelajaran yang dibuat guru kurang adanya inovasi dari guru, hal ini terlihat RPP yang dibuat guru sama dengan yang ada pada buku guru, seharusnya RPP direvisi oleh guru untuk mencapai tujuan pembelajaran, indikator kurang dianalisis oleh guru seharusnya indikator harus dianalisis sesuai dengan kata kerja operasional (kko).

Untuk mengatasi permasalahan di atas, Salah satu tindakan yang dapat dilakukan adalah dengan menggunakan strategi pembelajaran. Strategi pembelajaran merupakan cara yang dipilih untuk menyampaikan materi pembelajaran dalam lingkungan pembelajaran tertentu, (Adi, 2016:122). Strategi pembelajaran yang dapat diterapkan adalah menggunakan strategi pembelajaran inkuiri. Karena strategi pembelajaran inkuiri dapat mengembangkan keterampilan berpikir peserta didik untuk mencari dan menemukan sendiri pertanyaanpertanyaan dan mendapatkan jawaban atas dasar keingin tahuan mereka.

Menurut Wina (2013:208) strategi pembelajaran inkuiri mempunyai keunggunalan yaitu: (1) Strategi pembelajaran inkuiri merupakan strategi pembelajaran yang menekankan kepada pengembangan aspek kognitif, afektif, dan psikomotor secara seimbang, sehingga pembelajaran melalui strategi dianggap lebih bermakna. (2) Strategi pembelajaran inkuiri dapat memberikan ruang kepada siswa untuk belajar sesuai dengan gaya belajar mereka. (3) Strategi pembelajaran inkuiri merupakan strategi yang dianggap sesuai dengan perkembangan psikologi belajar modern yang menganggap belajar adalah proses perubahan tingkah laku berkat adanya pengalaman. (4) Strategi pembelajaran inkuiri dapat melayani kebutuhan siswa yang memiliki kemampuan di atas rata-rata.

Berdasarkan uraian diatas penelitian ini bertujuan untuk mendeskripsikan peningkatan hasil belajar tematik terpadu menggunakan strategi pembelajaran inkuiri di Kelas IV SDN 42 Kubang Kabupaten Pesisir Selatan.

\section{METODE PENELITIAN}

Penelitian ini menggunakan pendekatan kualitatif dan kuantitatif,dengan jenis penelitian yaitu Penelitian Tindakan Kelas (PTK). Penelitian tindakan kelas adalah penelitian praktis yang dimaksudkan untuk memperbaiki pembelajaran dikelas. Penelitian ini merupakan suatu upaya guru atau praktisi dalam bentuk berbagai kegiatan yang dilakukan untuk memperbaiki atau meningkatkan kualitas pembelajaran dikelas (Miaz,2015). Sedangkan Uno dkk (2012) menjelaskan bahwa Penelitian tindakan kelas adalah penelitian yang dilakukan oleh guru di dalam kelasnya sendiri melalui refleksi diri, dengan tujuan untuk memperbaiki kinerjanya sebagai guru, sehingga proses pembelajaran dapat berjalan dengan baik dan hasil belajar siswa meningkat.

Berdasarkan penjelasan di atas, dapat disimpulkan bahwa penelitian tindakan kelas adalah penelitian tindakan yang dilakukan didalam kelas yang bertujuan untuk memperbaiki praktik mengajar yang dilakukan oleh guru sehingga dapat meningkatkan proses pembelajaran agar berjalan dengan baik. 
Penelitian ini akan dilaksanakan pada semester I tahun ajaran 2020/2021. Penelitian ini dilakukan dalam II siklus. Siklus I pertemuan I dilaksanakan pada tanggal 14 september 2020, Siklus I pertemuan II dilaksanakan pada tanggal 21 september 2020. Siklus II dilaksanakan pada tanggal 28 september 2020. Adapun tempat penelitian dilaksanakan di SD Negeri 42 Kubang Kabupaten Pesisir Selatan.

Subjek dalam penelitian ini adalah peneliti sebagai praktisi (guru), guru kelas sebagai observer dan peserta didik kelas SDN 42 Kubang Kabupaten Pesisir Selatan yang terdaftar pada tahun ajaran 2020/2021. Dengan jumlah peserta didik 18 orang, terdiri dari 13 laki-laki dan 5 perempuan.

Prosedur penelitian ini terdiri dari 4 tahapan, yaitu: (1) tahap perencanaan terdiri dari menetapkan jadwal selama penelitian, menyusun rancangan tindakan berupa rencana pelaksanaanpembelajaran (RPP) berdasarkan tahapan pembelajaran, mendiskusikan dengan guru kelas IV tentang cara pengumpulan data menyusun alat data berupa lembar observasi pengamatan RPP, aspek guru dan siswa, (2) tahap pelaksanaan penelitian ini berdasarkan perencanaan yang telah disusun, peneliti sebagai praktisi, guru sebagai observer, peneliti dan guru melakukan diskusi, (3) tahap pengamatan, Pengamatan dilakukan oleh guru kelas pada waktu peneliti melaksanakan tindakan pembelajaran. Pengamatan dilakukan secara terus menerus dari siklus I sampai siklus II. Hasil pengamatan ini kemudian didiskusikan dengan guru kelas dan diadakan refleksi untuk perencanaan siklus berikutnya. (4) tahap refleksi dilakukan setiap satu tindakan berakhir. Refleksi yang dilakukan meliputi: Refleksi RPP berkenaan dengan rencana pelaksanaan pembelajaran tematik terpadu menggunakan strategi inkuiri dan refleksi aktivitas guru serta siswa dalam pembelajaran tematik terpadu menggunakan strategi inkuiri.

Data penelitian ini berupa hasil pengamatan dari setiap tindakan dalam pembelajaran tematik terpadu menggunakan strategi inkuiri, data tersebut berkaitan dengan perencanaan, pelaksanaan. Instrumen yang digunakan dalam penelitian ini lembar penilaian RPP, lembar observasi, Lembar tes dan non tes. Teknik pengumpulan data dikumpulkan dengan menggunakan dokumen analisis, observasi serta tes dan non tes

Analisis data pada penelitian ini dilakukan dengan data kualitatif dan kuantitatif, data yang didapat di lapangan didiskusikan dengan guru kelas kemudian di tulis dengan rapi. Model analisis data kualitatif yang dijelaskan oleh Miles dan Huberman (dalam Sugiyono, 2017:337) yaitu "Analisis data kualitatif dimulai dengan menelaah sejak mulai pengumpulan data sampai seluruh data terkumpul, data tersebut direduksi berdasarkan masalah yang diteliti, diikuti penyajian data dan terakhir penyimpulan atau verifikasi".

\section{HASIL DAN PEMBAHASAN}

Pelaksanaan penelitian tindakan kelas dibagi atas 2 siklus, dimana siklus I pertemuan 1 dan II yaitu Tema 8 (Daerah Tempat Tinggalku) subtema 1 (Lingkungan Tempat Tinggalku) pembelajaran 3 dan 4. siklus II subtema 2 (Keunikan Daerah Tempat Tinggalku) pembelajaran 3. Pelaksanaan siklus I pertemuan I dilaksanakan pada hari Senin tanggal 14 September 2020 mulai pukul 07.30-11:00 WIB.

Peneliti menganalisis setiap Kompetensi dasar yang akan dikembangkan dalam buku guru dan buku siswa kurikulum 2013 kelas IV tema 2 semester 1. Pada Kompetensi dasar pada mata pelajaran Bahasa Indonesia yaitu: 3.2 Mencermati keterhubungan antar gagasan yang didapat dari teks lisan, tulis, atau visual, 4.2 Menyajikan hasil pengamatan tentang keterhubungan antar gagasan ke dalam tulisan

Kompetensi dasar pada mata pelajaran IPA yaitu: 3.5 Mengidetifikasi berbagai sumber energi, perubahan bentuk energi, dan sumber energi alternatif (angin, air, matahari, panas bumi, bahan bakar organik, dan nuklir) dalam kehidupan sehari-hari, 4.5 Menyajikan laporan hasil pengamatan dan penelusuran informasi tentang berbagai perubahan bentuk energi. Kompetensi dasar pada mata pelajaran IPS yaitu: 3.1 Mengidentifikasi karakteristik ruang dan pemanfaatan sumber daya alam untuk kesejahteraan masyarakat dari tingkat kota/ kabupaten sampai tingkat provinsi 4.1 Menyajikan hasil identifikasi karakteristik ruang dan pemanfaatan sumber daya alam untuk kesejahteraan masyarakat dari tingkat kota/ kabupaten sampai tingkat provinsi. 
Pembelajaran pada penelitian ini dilakukan melalui tiga langkah, yaitu kegiatan awal, kegiatan inti, kegiatan akhir dengan strategi pembelajaran inkuiri. Penilaian Rencana Pelaksanaan Pembelajaran tematik terpadu menggunakan strategi pembelajaran inkuiri sebagai berikut: a) Pada aspek identitas mata pelajaran, sudah muncul 4 deskriptor dengan kualifikasi sangat baik (SB). b) Pada aspek perumusan indikator pembelajaran, sudah muncul 3 deskriptor dengan kualifikasi baik (B). c) Pada aspek perumusan tujuan pembelajaran, sudah muncul 2 deskriptor dengan kualifikasi cukup (C). d) Pada aspek pemilihan materi pembelajaran, sudah muncul 2 deskriptor dengan kualifikasi cukup (C). e) Pada aspek pemilihan sumber belajar, sudah muncul 3 deskriptor dengan kualifikasi baik (B). f) Pemilihan media pembelajaran, sudah muncul 3 deskriptor dengan kualifikasi baik (B) g) Pada Metode pembelajaran, sudah muncul 4 deskriptor yang muncul dengan kualifikasi sangat baik (SB). h) Pada skenario pembelajaran, sudah muncul 2 deskriptor yang muncul dengan kualifikasi cukup (C). i) Pada rancangan penilaian autentik, sudah muncul 4 deskriptor dengan kualifikasi sangat baik (SB).

Berdasarkan pengamatan yang dilakukan oleh observer pada pengamatan RPP siklus I pertemuan I persentase $75 \%$ dengan kriteria cukup (C).

Pengamatan proses pembelajaran tematik terpadu menggunakan strategi pembelajaran inkuiri pada aktivitas guru sebagai berikut: kegiatan awal deskriptor yang muncul 3 dengan kualifikasi baik (B). Kegiatan inti (a) orientasi, 4 deskriptor yang muncul kualifikasi sangat baik (SB). (b) merumuskan masalah, 2 deskriptor yang muncul kualifikasi cukup (C). (c) mengajukan hipotesis, 3 deskriptor yang muncul kualifikasi baik (B). (d) Mengumpulkan Data, 4 deskriptor yang muncul dengan kualifikasi sangat baik (SB). (e) Menguji hipotesis, 2 deskriptor yang muncul dengan kualifikasi cukup (C). (f) Merumuskan Kesimpulan, 3 deskriptor yang muncul dengan kualifikasi baik (B). kegiatan akhir deskriptor yang muncul 3 dengan kualifikasi sangat baik (B).

Berdasarkan hasil pengamatan yang dilakukan oleh pengamat terhadap aktivitas yang dilakukan peneliti dalam pembelajaran siklus 1 pertemuan 1 presentase nilai aktivitas guru ini adalah $75 \%$.

Pengamatan proses pembelajaran tematik terpadu menggunakan strategi pembelajaran inkuiri pada aktivitas siswa sebagai berikut: kegiatan awal deskriptor yang muncul 3 dengan kualifikasi baik (B). Kegiatan inti (a) Orientasi, 4 deskriptor yang munculkualifikasi sangat baik (SB). (b) merumuskan masalah, 2 deskriptor yang muncul kualifikasi cukup (C). (c) Mengajukan hipotesis, 3 deskriptor yang muncul kualifikasi baik (B). (d) Mengumpulkan Informasi, 4 deskriptor yang muncul dengan kualifikasi sangat baik (SB). (e) Menguji hipotesis, 2 deskriptor yang muncul dengan kualifikasi sangat cukup (C). (f) Merumuskan Kesimpulan, 2 deskriptor yang muncul dengan kualifikasi cukup (C). kegiatan penutup deskriptor yang muncul 3 dengan kualifikasi baik (B).

Berdasarkan hasil pengamatan yang dilakukan oleh pengamat terhadap aktivitas yang dilakukan peneliti dalam pembelajaran siklus 1 pertemuan 1 presentase nilai aktivitas guru ini adalah $71,87 \%$.

Pelaksanaan siklus I pertemuan II dilaksanakan pada hari Senin tanggal 21 September 2020 mulai pukul 07.30-11:00 WIB. Peneliti melakukan analisis setiap kompetensi dasar yang akan dikembangkan dalam buku guru dan siswa kurikulum 2013 kelas IV semester I. Pada kompetensi dasar mata pelajaran IPS yaitu: 3.1 Mengidentifikasi karakteristik ruang dan pemanfaatan sumber daya alam untuk kesejahteraan masyarakat dari tingkat kota/kabupaten sampai tingkat provinsi, 4.1 Menyajikan hasil identifikasi karakteristik ruang dan pemanfaatan sumber daya alam untuk kesejahteraan masyarakat dari tingkat kota/ kabupaten sampai tingkat provinsi. Kompetensi dasar mata pelajaran Bahasa Indonesia yaitu: 3.4 Membandingkan teks petunjuk penggunaan dua alat yang sama dan berbeda, 4.4 Menyajikan petunjuk pengamatan alat dalam bentuk teks tulis dan visual menggunakan kosa kata baku dan kalimat efektif.. Kompetensi dasar mata pelajaran IPA yaitu: 3.5 Memahami berbagai bentuk sumber enargi, dan sumber energi alternatif (angin, air, matahari, panas bumi, bahan bakar organik, dan nuklir) dalam kehidupan seharihari, 4.5 Menyajikan laporan hasil pengamatan dan penelusuran informasi tentang berbagai bentuk energy. 
Pelaksanaan pada penelitian ini dilakukan melalui tiga langkah, yaitu kegiatan awal, kegiatan inti, kegiatan akhir dengan menggunakan strategi pembelajaran inkuiri. Penilaian RPP tematik terpadu menggunakan strategi pembelajaran inkuiri sebagai berikut: a) identitas mata pelajaran, sudah muncul 4 deskriptor yang muncul dengan kualifikasi sangat baik (SB). b) perumusan indikator pembelajaran, sudah muncul 4 deskriptor yang muncul dengan kualifikasi sangat baik (SB). c) Pada aspek perumusan tujuan pembelajaran, sudah muncul 4 deskriptor yang muncul dengan kualifikasi sangat baik (SB). d) Pada aspek pemilihan materi pembelajaran, sudah muncul 3 deskriptor dengan kualifikasi baik (B). e) Pada aspek pemilihan sumber belajar, sudah muncul 3 deskriptor dengan kualifikasi baik (B). f) Pemilihan media pembelajaran, sudah muncul 3 deskriptor dengan kualifikasi baik (B). g) Pada Metode pembelajaran, sudah muncul 3 deskriptor dengan kualifikasi baik (B). h) Pada skenario pembelajaran, sudah muncul 3 deskriptor dengan kualifikasi baik (B). i) Pada rancangan penilaian autentik, sudah muncul 3 deskriptor dengan kualifikasi baik (B).

Berdasarkan pengamatan yang dilakukan oleh observer terhadap peneliti, persentase nilai RPP siklus II adalah $83,33 \%$ dengan kriteria baik (B).

Pengamatan pembelajaran tematik terpadu dengan strategi pembelajaran inkuiri pada aktivitas guru sebagai berikut: kegiatan awal 3 deskriptor sudah muncul dengan kualifikasi (B), kegiatan inti: a) orientasi, 4 deskriptor yang muncul dengan kualifikasi sangat baik (SB). b) merumuskan masalah, 3 deskriptor yang muncul dengan kualifikasi baik (B). C) Mengajukan hipotesis, 2 deskriptor yang muncul dengan kualifikasi sangat cukup (C). d) Mengumpulkan data, 4 deskriptor yang muncul kualifikasi sangat baik (SB). e) Menguji hipotesis, 4 deskriptor yang muncul dengan kualifikasi sangat baik (SB). f) Merumuskan Kesimpulan, 2 deskriptor yang muncul dengan kualifikasi cukup (C), kegiatan akhir 4 deskriptor muncul dengan kualifikasi sangat baik (SB).

Berdasarkan hasil pengamatan yang dilakukan oleh pengamat terhadap aktivitas yang dilakukan peneliti dalam pembelajaran siklus II nilai aktivitas guru adalah $84,37 \%$ dengan kualifikasi sangat baik (SB). Pengamatan pembelajaran tematik terpadu dengan strategi pembelajaran inkuiri pada aktivitas siswa sebagai berikut: kegiatan awal 3 deskriptor sudah muncul dengan kualifikasi (B), kegiatan inti: a) Orientasi, 4 deskriptor yang muncul dengan kualifikasi sangat baik (SB). b) merumuskan masalah, 3 deskriptor yang muncul dengan kualifikasi baik (B). c) Mengajukan hipotesis, 2 deskriptor yang muncul dengan kualifikasi cukup (C). d) Mengumpulkan data, 4 deskriptor yang muncul kualifikasi sangat baik (SB). e) Menguji hipotesis, 4 deskriptor yang muncul dengan kualifikasi sangat baik (SB). f) Merumuskan Kesimpulan, 2 deskriptor yang muncul dengan kualifikasi cukup (C), kegiatan akhir 4 deskriptor muncul dengan kualifikasi sangat baik (SB).

Berdasarkan hasil pengamatan yang dilakukan oleh pengamat terhadap aktivitas yang dilakukan peneliti dalam pembelajaran siklus II nilai aktivitas guru adalah $81,25 \%$ dengan kualifikasi baik (B).

Berdasarkan hasil pengamatan observer tentang perencanaan dan pelaksanaan proses pembelajaran tematik terpadu tujuan yang diharapkan pada pembelajaran siklus I pertemuan I dan 2 belum tercapai. Dengan demikian, upaya dalam peningkatan proses pembelajaran tematik terpadu menggunakan strategi pembelajaran inkuiri dapat dilakukan pada langkah-langkah proses pelaksanaan pembelajaran yang akan ditargetkan pada siklus II.

Pelaksanaan siklus II dilaksanakan pada hari Senin tanggal 28 Senin 2020 mulai pukul 07.00-11.00 WIB. Peneliti menganalisis setiap Kompetensi dasar yang akan dikembangkan dalam buku guru dan buku siswa kurikulum 2013 kelas IV tema 2 semester I. Pada kompetensi dasar mata pelajaran Bahasa Indonesia yaitu : 3.4 Membandingkan teks petunjuk penggunaan dua alat yang sama dan berbeda, 4.4 Menyajikan petunjuk penggunaan alat dalam bentuk teks tulis dan visual menggunakan kosakata baku dan kalimat efektif.

Kompetensi dasar mata pelajaran IPA yaitu : 3.5 Mengidentifikasi berbagai sumber enargi, perubahan bentuk energi dan sumber energi alternatif (angin, air, matahari, panas bumi, bahan bakar organik, dan nuklir) dalam kehidupan sehari-hari, 4.5 Menyajikan laporan hasil pengamatan dan penelusuran informasi tentang berbagai bentuk energi. Kompetensi dasar mata pelajaran IPS yaitu 3.1 Mengidentifikasi karakteristik ruang dan pemanfaatan 
sumber daya alam untuk kesejahteraan masyarakat dari tingkat kota/kabupaten sampai tingkat provinsi, 4.1 Menyajikan hasil identifikasi karakteristik ruang dan pemanfaatan sumber daya alam untuk kesejahteraan masyarakat dari tingkat kota/ kabupaten sampai tingkat provinsi.

Pelaksanaan pada penelitian ini dilakukan melalui tiga langkah, yaitu kegiatan awal, kegiatan inti, kegiatan akhir dengan menggunakan strategi pembelajaran inkuiri. Penilaian RPP tematik terpadu menggunakan strategi pembelajaran inkuiri sebagai berikut: a) identitas mata pelajaran, sudah muncul 4 deskriptor dengan kualifikasi sangat baik (SB). b) perumusan indikator pembelajaran, sudah muncul 4 deskriptor dengan kualifikasi sangat baik (SB). c) perumusan tujuan pembelajaran, sudah muncul 3 deskriptor dengan kualifikasi baik (B). d) pemilihan materi pembelajaran, sudah muncul 3 deskriptor dengan kualifikasi baik (B). e) pemilihan sumber belajar, sudah muncul 4 deskriptor dengan kualifikasi sangat baik (SB). f) Pemilihan media pembelajaran, sudah muncul 4 deskriptor dengan kualifikasi sangat baik (SB). g) Metode pembelajaran, sudah muncul 4 deskriptor dengan kualifikasi sangat baik (SB). h) skenario pembelajaran, sudah muncul 4 deskriptor dengan kualifikasi sangat baik (SB). i) rancangan penilaian autentik, sudah muncul 4 deskriptor dengan kualifikasi sangat baik (SB).

Berdasarkan pengamatan yang dilakukan oleh observer terhadap peneliti, persentase nilai RPP siklus II adalah $94,44 \%$ dengan kriteria sangat baik (SB). Pengamatan pembelajaran tematik terpadu dengan strategi pembelajaran inkuiri pada aktivitas guru sebagai berikut: kegiatan awal 4 deskriptor sudah muncul dengan kualifikasi (SB), kegiatan inti: a) Orientasi, 4 deskriptor yang muncul dengan kualifikasi sangat baik (SB). b) merumuskan masalah, 3 deskriptor yang muncul dengan kualifikasi baik (B). c) Mengajukan hipotesis, 4 deskriptor yang muncul dengan kualifikasi sangat baik (SB). d) Mengumpulkan Data, 4 deskriptor yang muncul kualifikasi sangat baik (SB). e) Menguji hipotesis,, 3 deskriptor yang muncul dengan kualifikasi baik (B). f) Merumuskan Kesimpulan, 4 deskriptor yang muncul dengan kualifikasi sangat baik (SB), kegiatan akhir 3 deskriptor muncul dengan kualifikasi baik (B). Berdasarkan hasil pengamatan yang dilakukan oleh pengamat terhadap aktivitas yang dilakukan peneliti dalam pembelajaran siklus II nilai aktivitas guru adalah 90,6\% dengan kualifikasi sangat baik (SB).

Pengamatan pembelajaran tematik terpadu dengan strategi pembelajaran inkuiri pada aktivitas siswa sebagai berikut: kegiatan awal 4 deskriptor sudah muncul dengan kualifikasi (SB), kegiatan inti: a) Orientasi, 4 deskriptor yang muncul dengan kualifikasi sangat baik (SB). b) merumuskan masalah, 3 deskriptor yang muncul dengan kualifikasi baik (B). c) Mengajukan hipotesis, 3 deskriptor yang muncul dengan kualifikasi baik (B). d) Mengumpulkan data, 4 deskriptor yang muncul kualifikasi sangat baik (SB). e) Menguji hipotesis, 3 deskriptor yang muncul dengan kualifikasi baik (B). f) Merumuskan Kesimpulan, 4 deskriptor yang muncul dengan kualifikasi sangat baik (B), kegiatan akhir 3 deskriptor muncul dengan kualifikasi baik (B). Berdasarkan hasil pengamatan yang dilakukan oleh pengamat terhadap aktivitas yang dilakukan peneliti dalam pembelajaran siklus II nilai aktivitas guru adalah $87,5 \%$ dengan kualifikasi sangat baik (SB).

Berdasarkan pengamatan pelaksanaan pembelajaran dari aktivitas guru dan siswa siklus II menunjukkan bahwa penerapan strategi pembelajaran inkuiri pada proses pembelajaran tematik terpadu sudah meningkat dan terlaksana dengan baik. Dengan demikian, penelitian hasil belajar menggunakan strategi pembelajaran inkuiri tidak dilanjutkan pada siklus berikutnya.

\section{SIMPULAN}

Berdasarkan hasil penelitian dan pembahasan peneliti dapat menyimpulkan bahwa hasil penelitian menunjukkan pada RPP siklus I 79,16\% (C) meningkat pada siklus II menjadi $94,44 \%$ (SB). Pelaksanaan pembelajaran pada kegiatan guru siklus I 76,56\% (C), meningkat pada siklus II menjadi $87,5 \%$ (B). Pelaksanaan pembelajaran pada kegiatan siswa siklus I $78,52 \%$ (C), meningkat pada siklus II menjadi 90,82\% (SB). Dengan demikian penelitian dengan menggunakan strategi pembelajaran inkuiri dapat meningkatkan hasil belajar tematik terpadu di Sekolah Dasar. 


\section{DAFTAR PUSTAKA}

Adi Winanto \& Darma Makahube. 2016. Implementasi Strategi Pembelajaran Inkuiri untuk Meningkatkan Motivasi dan Hasil Belajar IPA Siswa Kelas 5 SD Negeri Kutowinangun 11 Kota Salatiga. Scholaria, Vol. 6 No. 2, $119-138$.

Desyandri. (2018). Nilai-nilai Kearifan Lokal untuk Menumbuhkembangkan Literasi Budaya di Sekolah Dasar. Sekolah Dasar: Kajian Teori Dan Praktik Pendidikan, 27(1), 1-9. http://doi.org/http://dx.doi.org/10.17977/um009v27i12018p001.

Hamzah B. Uno, dkk. 2012. Menjadi Peneliti PTK yang Profesional. Jakarta: Bumi Aksara.

Juita Purnamasari, Yunisrul, \& Desyandri. 2018. Peningkatan Pembelajaran Tematik Dengan Pendekatan Scientific Di Kelas I Sdn 15 Ulu Gadut Kota Padang. e - Jurnal Inovasi Pembelajaran SD. Voleme 6, No 1, 11-24.

Nadya Yolanda, Reinita. 2019. Pembelajaran Tematik Terpadu Dengan Menggunakan Model Quantum Teching. Journal of Elemantary School (JOES).Volume :2 , No:2, 72.

Nia Susanti, Hamimah, \& Reinita. 2019. Peningkatan Hasil Belajar Siswa Menggunakan Metode Pembelajaran Cooperative Learning Tipe Co-Op Co-Op Dalam Pembelajaran IPS di Kelas V SD. e - Jurnal Inovasi Pembelajaran SD. Volume 7, No , 10-21.

Satria Efendi, Reinita. 2019. Peningkatan Aktivitas Belajar Siswa Pada Pembelajaran Tematik Menggunakan Pendekatan VCT Model Matriks di SDN 36 Cengkeh Kota Padang. e-Jurnal.unp.ac.id/index.php/bahana. Volume 8, No 2, 70.

Sa'dun Akbar, dkk. 2016. Implementasi Pembelajaran Tematik di Sekolah Dasar. Bandung: PT Remaja Rosdakarya.

Sugiyono. 2017. Metode Penelitian Pendidikan Pendekatan Kuantitatif, Kualitatif, dan R\&D. Bandung: Alfabeta.

Wina Sanjaya. 2013. Strategi Pembelajaran Berorientasi Standar Proses Pendidikan. Jakarta: Kencana. 